Igor Molchanov

\title{
Szakképzés, munkaerőpiac és bevándorlás-politika Oroszországban
}

Molchanov, Igor:

Профессиональное образование, рынок труда и миграционная политики в России Vocational Training, Labor Market and Immigration Policy in Russia

In point of view of labour market the immigration has become the major factor in recent times. The main tasks of immigration policy: compensation of labour shortages in relation with demographic and aging population problems; to satisfy the long-term demand for labour in some business sectors; to ensure the labor supply of innovation-qualified investment processes; organizing of preparation of experts from requested profession; to limit the short-term unskilled labor immigration; creating the necessary conditions and broaden the opportunities for immigration for business use.

Keywords: vocational training, labor market, immigration policy

Внешняя трудовая миграция становится одним из главных вопросов демографической, экономической и социальной политики Российского государства. Миграционную политику целесообразно направить на решение следующих задач: компенсирование недостатка рабочей силы, связанной с демографическими проблемами и старением населения; удовлетворение устойчивого спроса на рабочую силу в отдельных секторах экономики; обеспечение квалифицированной рабочей силой инновационноинвестиционных процессов; налаживание подготовки кадров востребованных профессий и квалификаций; ограничение краткосрочной неквалифицированной миграции; создание условий и расширение возможностей для деловой иммиграции.

Ключевые слова: профессиональное образование, рынок труда,и миграционная политики,

\section{ÖSSZEFOGLALó}

A bevándorlás a munkaerőpiac szempontjából az oroszországi munkaerőpiac meghatározó tényezőjévé vált az utóbbi időben. $A$ bevándorláspolitika fóbb feladatai: a munkaerőhiány kompenzálása, amely a demográfiai problémák és a lakosság elöregedésével van összefüggésben; a tartós munkaerő-kereslet kielégítése egyes gazdasági szektorokban; az innovációs-beruházási folyamatok kvalifikált munkaerő-ellátásának biztosítása; az igényelt szakmák megfelelő képesítésű szakemberei felkészítésének megszervezése; a rövidtávú képzetlen munkaerő-bevándorlás korlátozása; a szükséges feltételek megteremtése és a lehetőségek kiszélesítése az üzleti céllal történő bevándorlás számára.

Kulcsszavak: szakképzés, munkaerőpiac, bevándorlás politika

A külső munkaerő-piaci bevándorlás az utóbbi időben az orosz állam demográfiai, gazdaság- és szociálpolitikájának egyik legfontosabb kérdésévé vált. A bevándorlás-politikát célszerű a következő feladatok megoldása felé irányítanunk:

- A munkaerőhiány kompenzálása, amely a demográfiai problémák és a lakosság elörege- 
désével van összefüggésben,

- A tartós munkaerő-kereslet kielégítése egyes gazdasági szektorokban,

- Az innovációs-beruházási folyamatok kvalifikált munkaerő-ellátásának biztosítása,

- Az igényelt szakmák megfelelő képesítésú szakemberei felkészítésének megszervezése

- A rövidtávú képzetlen munkaerő-bevándorlás korlátozása,

- A szükséges feltételek megteremtése és a lehetőségek kiszélesítése az üzleti céllal történő bevándorlás számára.

A megnevezett feladatok megvalósításához egy sor gyakorlati jellegű lépést kell megtennünk. Mindenek előtt nagyobb átláthatóságot és rugalmasságot kell kialakítani a munkáltatói és munkavállalói bevándorlás folyamataiban, át kell térni a külföldi munkaerő bevonásának és kihasználásának szabályozása terén a túlnyomóan adminisztratív módszerekről a gazdasági módszerekre.

A munka alapvető irányai a következők lehetnek:

- A bevándorlók azon célcsoportjainak meghatározása, amelyekben érdekelt az Orosz Föderáció,

- A képzett és képzetlen bevándorló munkaerőbevonás megközelítésének differenciálása,

- A külföldi munkaerő bevonásával és kihasználásával kapcsolatos fölösleges adminisztrációs procedúrák csökkentése és a munkáltatók megnövekedett kötelezettségeinek átvizsgálása, ide tartozik pl. a munkáltató által rendelkezésre bocsátandó dokumentumok jegyzéke, ezen igazolások tartalma, stb., továbbá a büntetőjogi szankciók (pl. a jogszabályok megszegése esetében jogi személyeknél max. 80.000 rubel büntetés bármelyik külföldi állampolgárra vagy állampolgárság nélküli személyre vonatkozóan, ill. a tevékenységének legfeljebb 90 napig tartó adminisztratív felfüggesztése).

- A gazdasági munkaerő-szükséglet meghatározásának, modern módszertanának és eszközeinek alkalmazása, ugyanakkor a kvótarendszer alkalmazásterületének pontos felosztása.
A meglévő gyakorlat javítására javasolni lehetne a betöltetlen állások nyiltt alapon múködő meghirdetését egy bizonyos időszakon belül (pl. egy hónap), amelynek a letelte után a munkáltató megkapja azt a jogot, hogy külföldi munkáltatót alkalmazzon, a kiválasztás megszervezésének intézkedéseit kidolgozza, a bevándorlót kiképezze és elhelyezze, $s$ amennyiben új munkahely-teremtésről van szó, a bevándorló vállalkozó ösztönzésére eszközöket dolgozzon ki.

Ezen programok különlegessége abban áll, hogy a bevándorlók prioritást élvező csoportjai alapján jönnek létre, és e csoportok mentén határozzák meg a bevándorlás-politika irányvonalait, a csoportonként kialakított bevonási alapfeltételeket, a bevándorlók kiválasztásának rendjét és feltételeit, meghatározzák a munkavállalás hosszát, korlátozását, körülményeit, illetve az Oroszország területén való tartózkodást.

A programokban való gondolkodás lehetővé teszi, hogy

- optimalizáljuk az az engedélyek kiadásának és a munkavállaló bevándorlók számontartásának folyamatát,

- csökkentsük az engedélyek megadásához szükséges időbeli és anyagi költségeket,

- biztosítsunk érthető, operatív és kényelmes munkamenetet a munkavállalók alkalmazásánál,

- konkretizáljuk az orosz törvényhozás szabályait a külföldi munkavállalók különböző kategóriáival kapcsolatosan.

A lefolytatott kutatás lehetővé tette a bevándorlási hullámok strukturálását, a különböző bevándorlói csoportok sajátosságainak kimutatását és a számukra kialakított feltételek megfogalmazását.

A külföldi munkavállalók bevonásának célprogramjai szorosan összefüggenek a bevándorló magánszemélyek áramlásával, amelyhez a következők tartoznak:

- szakember-bevándorlás,

- üzletember-bevándorlás.

- a külföldi munkavállalók munkáltatói igény szerinti bevonása,

- tanulói bevándorlás. 
Tekintsük át a fent nevezett csoportokat részletesebben.

\section{SZAKEMBER-BEVÁNDORLÁS}

A szakember-bevándorlás legfóbb célja az, hogy olyan magasan kvalifikált szakembereknek biztosítsuk a folyamatos beáramlást, akiknek a végzettségére és a szakmai tapasztalatára szükség van Oroszországban.

Ide tartoznak

- a nemzetközileg elismert, a tudomány, a művészetek, az oktatás és az üzleti élet, továbbá a sport területén kiemelkedő képességekkel rendelkező személyek, kiváló professzorok, kutatók, nemzetközi menedzserek.

- a mesterfokozatnak (MA / MSc) megfelelő felsőfokú végzettséggel rendelkező személyek, illetve rendkívüli képességekkel rendelkező tudósok, művészek és üzletemberek,

- olyan minősített szakemberek, akik nemrégiben végeztek az igényelt szakágazatok alapdiplomát (BA/BSc) nyújtó oktatási intézményeiben.

A fent felsorolt bevándorló csoportok migrációs programjai a végleges és ideiglenes letelepedés támogatását célozzák meg. Számukra az országban való tartózkodási jog minimum 1 évre kell, hogy szóljon, amelyet 5 évre lehet meghosszabbítani, továbbá a letelepedési engedély kiadásának feltételeit is könnyíteni kell. A munkaerő-bevonás céljából a következő általános alapfeltételeket érdemes meghatározni:

- a munkáltatói meghívás nélküli beutazás lehetősége,

- bizonyos ideig (pl. 1 évig) történő önálló munkakeresési lehetőség biztosítása.

$\mathrm{Az}$ adott csoportok bármelyikére lehet preferenciákat ás korlátozásokat meghatározni. PI. Nem kell kötelezővé tenni, hogy egy bizonyos munkáltatónál helyezkedjen el a munkavállaló és a munkavállalási engedély kiadásához sem szükséges követelményeket szabni.
Ugyanakkor az első csoporthoz tartozó munkavállalók esetében meghatározható a keresett szakmák listája, de nem kell mennyiségi korlátozást (kvótát) előírni. A második csoport esetében mind a keresett szakmák listája, mind a mennyiségi korlátozás feltétlenül szükséges, a harmadik csoportban csak a mennyiségi korlátozás alkalmazandó.

Ezen túlmenően más korlátozások is bevezetésre kerülhetnek, pl. a már letöltött munkaviszony hossza vagy a végzettség.

\section{ÜZLETEMBER-BEVÁNDORLÁs}

Az üzletember-bevándorlás fő célja, hogy olyan üzletembernek biztosítsunk folyamatos beáramlást, akik beruházni kivánnak vagy új üzletágat szeretnének kialakítani, azaz :

- vállalkozók,

- beruházók,

- magánvállalkozók, és azok kísérői, kisegítői.

\section{Vállalkozók}

Azon személyek bevándorlása, akik már sikeres vállalkozást tudtak elindítani Oroszországban, ne legyen kötve a munkáltatói meghíváshoz. A válogatás kidolgozott kritériumok alapján történhet, vagy bizonyos követelmények állíthatók számukra, pl.

- rendelkezzenek pénzügyi tartalékokkal,

- legyen vállalkozói tapasztalatuk,

- invesztáljanak egy bizonyos nagyságú tókét a gazdaságba,

- teremtsenek bizonyos mennyiségű munkahelyet a helyi munkaerő számára.

Oroszország területén való tartózkodás egy sor követelmény teljesítéséhez legyen kötve, pl.

- legyen kötelező egy már meglévő üzletet üzemeltetni vagy újat létrehozni,

- a bevándorló vegyen aktívan részt az üzlet irányításában,

- teremtsen minimum egy helyi lakos számára 
(aki nem családtagja az üzletembernek) betölthető új munkahelyet,

- az adott üzletből való részesedése minimum $1 / 3$ legyen.

- A kezdeti időtartamot lehet két évre korlátozni (üzleti vízum) azzal kiegészítve, hogy az adott letelepedési típust könnyített eljárással szerezheti meg.

\section{Beruházók}

Az adott típusú bevándorlói csoport beutazása se legyen kötve munkáltatói meghíváshoz, de kiválasztásuk kidolgozott kritériumok alapján történhet vagy munkavállalásukat bizonyos kötelezettségek teljesítéséhez köthetjük, pl. invesztáljon az orosz gazdaságba bizonyos nagyságú tőkét. Az Oroszország területén való tartózkodás számos követelmény teljesítésével járjon, pl.

- a vállalkozó vegyen részt saját tőkéjével egy már működő vállalkozásban vagy

- invesztáljon saját pénzeszközöket állami programokba, alapítványokba öt vagy több éven keresztül.

\section{Magánvállalkozók}

A magánvállalkozók bevándorlása se legyen kötve a munkáltatói meghíváshoz. A válogatás kidolgozott kritériumok alapján történhet, vagy bizonyos követelmények állíthatók számukra, pl. bizonyítsák be, hogy van lehetőségük saját vállalkozást indítani, ebből képesek eltartani magukat és sikeresen fejlesztik is üzletüket.

A bevándorlás ezen típusának az előnye, hogy nem szükséges új munkahelyet teremteni illetve beruházni. A kiválasztás bizonyos tevékenységi körök alapján történhet, azaz az országban leginkább keresett szakmák listája alapján. A tartózkodás lehet állandó vagy ideiglenes. A kezdeti időtartam két évre szólhat, továbbá a bevándorló az adott letelepedési típust könnyített eljárással szerezheti meg.

\section{KÜLFÖLDI MUNKAVÁLLALÓK}

A külföldi munkavállalók munkáltatói kérelem alapján történő bevonásának célja, hogy a z adott munkaerőhiányt korlátozott számú bevándorló alkalmazásával lefedjük, de csak abban az esetben, ha a belföldi munkaerőpiacon kiírt állásra nincs jelentkező. Ide tartoznak

- a széles skálán mozgó foglalkozásokkal és képzettséggel rendelkező szakemberek,

- nem szakmunkát végző munkavállalók, többek között a 17-től 27 éves korig terjedő korosztály,

- képzettséget nem megkövetelő mezőgazdasági és építőipari dolgozók,

- a szolgáltatásban és a kereskedelemben dolgozók.

Széles skálán mozgó foglalkozásokkal és képzettséggel rendelkező szakemberek

Az adott típusú bevándorlók számára menynyiségi korlátozást (kvótarendszert) kell meghatározni, és létre kell hozni a prioritást élvező szakmák listáját.

A meghívott munkavállalónak rendelkeznie kell konkrét munkáltatóhoz, egy bizonyos munkahelyre és korlátozott időre szóló munkavállalói engedéllyel, továbbá meg kell szabni, hogy

- nem változtathat munkáltatót,

- nem végezhet a vízumkérő lapon megadott pozíciótól eltérő munkát,

- nem dolgozhat párhuzamosan más munkáltatónál.

Munkaviszonyban töltött időre és végzettségre vonatkozó követelményeket is célszerü bevezetni és legfeljebb öt évre szóló tartózkodást lehetővé tenni.

Nem szakmunkát végző munkavállalók, többek között a 17-től 27 éves korig terjedő korosztály

A munkaerő bevonáshoz mennyiségi korlátokat kell meghatározni. Ilyen típusú bevándorlók csak bizonyos munkáltatónál egy bizonyos mun- 
kahelyen helyezkedhetnek el, és csakis erre a munkahelyre, bizonyos időszakra szóló munkavállalási engedély állítható ki számukra.

A kiválasztás pontozási rendszerrel történjék. A végzettségre vonatkozóan ne legyenek előirások, viszont a prioritást élvező, hiányszakmáknak számító munkakörök listája mindenképpen legyen kiválasztási szempont. Ilyen munkakörök lehetnek pl. a szociális munkás vagy a fiatal egészségügyi dolgozó. A maximális munkavállalási idő lehet két év a munkavállalói státusz megváltoztatása nélkül. Ezen kategórián belül külön csoportot képeznek a 17-27 éves fiatal munkavállalók, akik szakképesítés nélkül kerülnek munkaviszonyba, fóként az iskolai szünetek időszakaiban. Számukra külön programok kidolgozása javasolt.

\section{Képzettséget nem megkövetelő} mezőgazdasági és építőipari dolgozók

A kiválasztás pontozási rendszerrel történjék. A végzettségre vonatkozóan ne legyenek előirások, viszont élvezzen előnyt az Orosz Föderációban már megszerzett munkatapasztalat és a nyelvismeret megléte. Kiválasztásukhoz a kvótarendszer a legalkalmasabb. A munkavállalónak rendelkezni e kell konkrét munkáltatóhoz, egy bizonyos munkahelyre és korlátozott időre szóló munkavállalói engedéllyel. A maximális tartózkodási idő 6 hónap lehet (ideiglenes tartózkodás) a munkavállalói státusz megváltoztatása nélkül.

\section{Szolgáltatásban és}

\section{a kereskedelemben dolgozók}

A kiválasztáshoz ebben az esetben is pontozási rendszer javasolt. A végzettségre vonatkozóan sem szükségesek előírások, viszont jelentsen előnyt az Orosz Föderációban már megszerzett munkatapasztalat és a nyelvismeret. A külföldi munkaerő bevonásához kvótarendszert kell kialakítani, továbbá az adott munkavállaló csak egy bizonyos munkáltatónál helyezkedhet el. A munkavállalónak rendelkeznie kell konkrét munkáltatóhoz, egy bizonyos munkahelyre és korlátozott időre szóló munkavállalói engedélylyel. A maximális tartózkodási idő 2 év lehet (ideiglenes tartózkodás) a munkavállalói státusz megváltoztatása nélkül.

\section{Tanulási célú bevándorlás}

A tanulói, tanulási céllal történő bevándorlás célja a magasan képzett szakemberek versenyelőnyének megteremtése. A kedvezményezett csoportok olyan diákok és fiatal felnőttek, akik részképzésben vesznek részt.

A végzős főiskolai és egyetemi hallgatók jogosultak közvetlenül a tanulmányaik befejezése után munkát vállalni az országban munkaviszonyban eltöltött évek számától függetlenül. Munkavállalási engedély kiadható mind a tanulmányi idő alatt, mind a diploma megszerzése után. A munkavállalási engedélyt minden esetben könnyített eljárással szerezhetik meg. Ilyen típusú bevándorlók esetében nem kell kvótarendszert alkalmazni. Egy bizonyos munkahelyen történő elhelyezkedés után a bevándorló saját kívánsága szerint szerezhet ideiglenes vagy állandó letelepedési engedélyt.

A hazai törvényhozás alapját a „Külföldi állampolgárok jogállásáról szóló rendelet" képezi. Az orosz munkaerőpiac egyensúlyának fenntartása érdekében elengedhetetlen a normatív jogi alapok jelentős javítása, amely lehetővé tenné

- a külföldi munkavállalók kiválasztásának hatékony mechanizmusát,

- a bevándorlók és a munkáltatók érdekeinek összehangolását,

- a családok újraegyesítésének figyelembe vételét, azaz a külső munkaerő-bevándorlás bonyolult feladatrendszerének sokrétű és komplex megoldási módját.

A bevándorlás-politika fent kifejtett intézkedéseinek pontos kidolgozása és megvalósítása minden bizonnyal hozzájárulna a lakosság képzési szintjének emeléséhez, a munkaerőpiac stabilizálásához, továbbá Oroszország és régiói kvalifikált munkaerővel való ellátásához. 